USE OF DOUBLE-MASS CURVES TO DETERMINE DRAWDOWN IN A LONG-TERM AQUIFER TEST IN NORTH-CENTRAL VOLUSIA COUNTY, FLORIDA

By A. T. Rutledge

U.S. GEOLOGICAL SURVEY

Water-Resources Investigations Report 84-4309

Prepared in cooperation with

VOLUSIA COUNTY

Tallahassee, Florida 


\section{UNITED STATES DEPARTMENT OF THE INTERIOR \\ DONALD PAUL HODEL, Secretary \\ GEOLOGICAL SURVEY \\ Dallas L. Peck, Director}

For additional information

write to:

District Chief

U.S. Geological Survey

Suite 3015

227 North Bronough St.

Tallahassee, Florida 32301
Copies of this report

can be purchased from:

Open-File Services Section Western Distribution Branch U.S. Geological Survey Box 25425, Federal Center Denver, Colorado 80225 (Telephone: (303) 236-7476) 
Abstract

Introduction -

Environmental setting 3

Geographic setting 3

Geohydrologic setting - 3

Preliminary test -

Long-term aquifer test design and data collection

Pumpage - 9

Data collection - 9

Description of double-mass curves - 12

Response in the Floridan aquifer system 15

Response in the surficial aquifer 19

Conclusions -

Selected references - 29

\section{ILLUSTRATIONS}

Figure 1. Map showing location of north-central Volusia County, geographic features, and data-collection sites -

2. Diagram showing lithologic and natural gamma logs of well 2A

3. Map showing potentiometric surface of the upper part of the Floridan aquifer system and water levels in wells of the Floridan aquifer system and surficial aquifer, May 1978

4-5. Graph showing:

4. Drawdown in the Floridan aquifer system during the 1976 aquifer test -

5. Ratio of drawdown in the surficial aquifer to drawdown in the Floridan aquifer system as a function of time -....

6. Idealized hydrograph and double-mass curve showing the water-level record in observation wells before, during, and after a period of pumping from another well -.-.--

7. Hydrograph showing daily maximum water levels in wells U. C. Deep, Mile West Middepth, and I-4 Deep, and daily minimum water levels in well 4A, January 1978 to September 1980 


\section{ILLUSTRATIONS--Continued}

Page

Figure 8-10. Double-mass curve of water-level data:

8. For 4A well and U. C. Deep well for the period April 25, 1978 to January 4, 1980 ..................

9. For Mile West Middepth well and U. C. Deep well for the period April 25, 1978 to October 31, $1979 \ldots 18$

10. For I-4 Deep well and U. C. Deep well for the period April 25, 1978 to October 31, 1979 -.......... 20

11-12. Hydrograph showing daily maximum water levels:

11. In well 350-foot Shallow and daily minimum water levels in well 4A, January 1978 to September

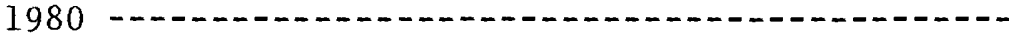

12. In wells I-4 Shallow, 350-foot Shallow, Mile West Shallow, and U. C. Shallow, January 1978 to September 1980

13-15. Double-mass curve of:

13. Water-level data for 1,000-foot Shallow well and U. C. Shallow well for the period April 25, 1978 to November 1, 1979

14. Water-level data for Mile West Shallow well and U. C. Shallow well for the period April 25, 1978 to September 10, 1979

15. Water-level data for 1,000-foot Shallow well and Mile West Shallow well for the period April 25, 1978 to September 11, 1979

16. Rainfall data for East Rain gage and Mile West Rain gage for the period April 1978 to June 1979

TABLE

Table 1. Depths, locations, and other data concerning wells used 


\title{
USE OF DOUBLE-MASS CURVES TO DETERMINE DRAWDOWN \\ IN A LONG-TERM AQUIFER TEST IN NORTH-CENTRAL \\ VOLUSIA COUNTY, FLORIDA
}

By A. T. Rutledge

\begin{abstract}
A wetlands area in central Volusia County has the potential to be an important recharge area of the Floridan aquifer system if pumping increases the downward hydraulic gradient. The source of the increased recharge is capture of water from the surficial aquifer and wetlands environment. This capture will probably cause a drawdown in the water table in the surficial aquifer. To evaluate this drawdown, a well open to the Upper Floridan aquifer was pumped at an average rate of 530 gallons per minute from June 30,1978 , to July 17, 1979. Ground-water level data were collected at nine wells in the surficial aquifer and six wells in the Floridan aquifer system before, during, and after the pumping period.

Double-mass curves were used to separate the drawdown from natural waterlevel fluctuations. Drawdown can be detected and quantified using changes in slope on the double-mass curve.

The drawdowns were calculated for the Upper Floridan aquifer by comparing data from observation wells to data from a control well open to that zone but located 7.1 miles northwest of the pumping well as the control well. The drawdowns calculated when the pumpage was 560 gallons per minute were 4.3 feet at a site 350 feet northeast of the pumped wel1, 4.1 feet at a site 1,000 feet northwest of the pumped well, 1.0 foot at a site 1.0 mile west of the pumped well, and 0.4 foot at a site 5.8 miles south of the pumped well.

Very little drawdown occurred in the water table of the surficial aquifer. Because it was small, drawdown in that aquifer was difficult to assess. After an initial drawdown of 0.2 foot at a surficial aquifer well 1,000 feet from the pumped well, there was some recovery, and long-term drawdown averaged less than 0.2 foot. The drawdown 1.0 mile from the pumped well was too small to measure.

The results of a 5-day aquifer test conducted during a period of no rainfall in 1976 indicated that the ratio of surficial aquifer drawdown to Floridan aquifer system drawdown at the test site reached an apparent equilibrium at 0.05 . The results of the long-term test indicate that this ratio is the upper limit of the water-table drawdown. The actual long-term drawdown is less than the drawdown indicated by this ratio because of greater capture of evapotranspiration and streamflow during the long-term test.
\end{abstract}


Using the principle of superposition, some of the results of this test may be extrapolated to determine the drawdown in both the surficial aquifer and the Upper Floridan aquifer that would occur given a larger pumping rate.

\section{INTRODUCTION}

North-central Volusia County is a sparcely populated area of approximately 70-square miles west of the city of Daytona Beach. Growth in the cities of Daytona Beach, New Smyrna Beach, Ormond Beach, and adjacent communities continues to increase the demand for potable water. The 1980 water-use rate of the east half of Volusia County was approximately 35 million gallons per day (Mgal/d). Because of saltwater intrusion in the Floridan aquifer system, many municipal supply wells have been abandoned in past decades and replaced by new wells farther to the west.

North-central Volusia County, which is adjacent to the coastal municipalities, has an abundant supply of freshwater. This water occurs as (1) surface water in streams and lakes, (2) ground water in the surficial aquifer which is 15 to 70 feet thick and 80 to 100 percent saturated, and (3) ground water in the Floridan aquifer system which is completely saturated with freshwater through a 700- to 1,400-foot thickness. Central Volusia thus contains a large and presently unused reserve of freshwater which could be a source for the coastal areas.

Water managers are concerned about the possible long-term drawdown of the water table in the surficial aquifer that could be caused by pumping from the underlying Floridan aquifer system. It is apparent that some water table drawdown must exist so that capture from streamflow or evapotranspiration can occur, but the amount of water-table drawdown resulting from a given drawdown in the Floridan aquifer system is unknown.

The purpose of this investigation was to determine the long-term drawdown in both aquifer systems. The study was performed in cooperation with Volusia County. The county installed and maintained a test pump which withdrew water from the Floridan aquifer system from June 1978 to July 1979 at an average rate of 530 gallons per minute (gal/min). The U.S. Geological Survey maintained water-level records and rainfall records before, during, and after this pumping period. Water-level records were collected at test sites near the pumped well and also at "control" wells that were so far from the pumped well that little or no drawdown was expected.

This report documents the methods used and the results obtained in determining the drawdowns that resulted from this test pumping. Double-mass curves were used to separate the drawdown caused by pumping from natural water-level fluctuations. Although double-mass curves may be widely applicable in determining whether or not drawdown occurs, the method used in this report should be used only if the drawdown due to stress reaches the state of equilibrium. 


\section{ENVIRONMENTAL SETTING}

\section{Geographic Setting}

North-central Volusia County is roughly defined as the part of the Talbot Terrace bounded to the north by State Road 40, to the south by U.S. Highway 92 , and to the west by State Road 11 and Marsh Road (fig. 1). Land surface altitudes in the area range from 30 feet in the northeast to 70 feet in the southwest. The altitude is generally 30 to 45 feet in the center of the study area (fig. 1). The land surface in the area is a flat terrace, which among other terraces, is described by Wyrick (1960).

Unlike the well-drained De Land Ridge area (fig. 1), the study area is predominantly a wetlands environment that is characterized by surface drainage into streams instead of downward drainage into the Floridan aquifer system. Major surface drainage systems in the area are: the Little Haw Creek basin in the west, the Middle Haw Creek basin in the north, the Tomoka River basin in the east, the Spruce Creek basin in the southeast, and the Deep Creek basin in the southwest.

\section{Geohydrologic Setting}

The lithology at well $2 \mathrm{~A}$ is shown in figure 2. The sand beds from land surface to 50 feet are of Holocene and Pleistocene age and form the surficial aquifer. The shell and clay layers from 50 to 90 feet are of Miocene age. The composite of the clay layers therein make up the confining bed between the surficial aquifer and the Floridan aquifer system. The limestone layers below the confining bed are of Eocene age and comprise the Floridan aquifer system. The limestone formations penetrated by well 2A are the Ocala Limestone and the underlying Avon Park Formation.

Estimates of hydraulic properties of the Floridan aquifer system in Volusia County were given by Bush (1978). The transmissivity of the Floridan aquifer system in north-central Volusia County was estimated to be approximately 13,000 feet squared per day $\left(\mathrm{ft}^{2} / \mathrm{d}\right)$. The leakance, considering just the overlying confining bed, generally ranges from $0.02 \mathrm{yr}^{-1}$ to $0.04 \mathrm{yr}^{-1}$

Outflow from the surficial aquifer occurs as (1) evapotranspiration, (2) streamflow, and (3) downward leakage to the Floridan aquifer system. Downward leakage under natural conditions is small. This downward flow is induced by a downward hydraulic head gradient. The water table in the surficial aquifer averages 0 to 5 feet below land surface, whereas the potentiometric surface of the Floridan aquifer system averages 2 to 12 feet below land surface in the study area. Bush (1978) estimated natural recharge rates of 0 to 3 inches per year for the north-central Volusia County area.

Figure 3 shows the areal distribution of hydraulic head, or potentiometric surface, for the Upper Floridan aquifer. Also shown at a few locations is the surficial aquifer head, as measured in a few wells. The difference between the head of the surficial aquifer and the head of the Floridan aquifer system for a given location is the driving force for leakage through the confining layer at that location. The general directions of horizontal surface drainage are also shown in figure 3 . 


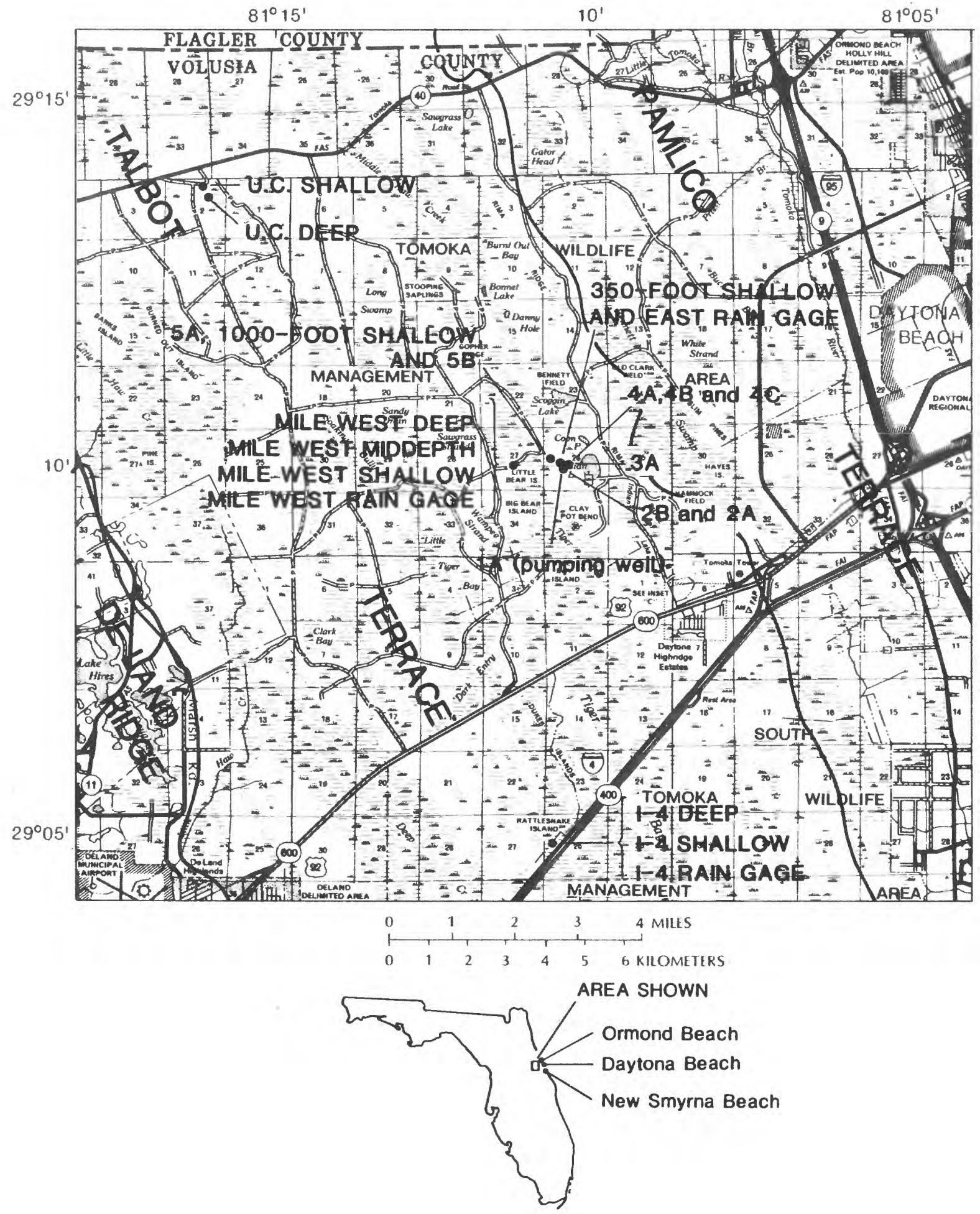

Figure 1.--Location of north-central Volusia County, geographic features, and data-collection sites. 


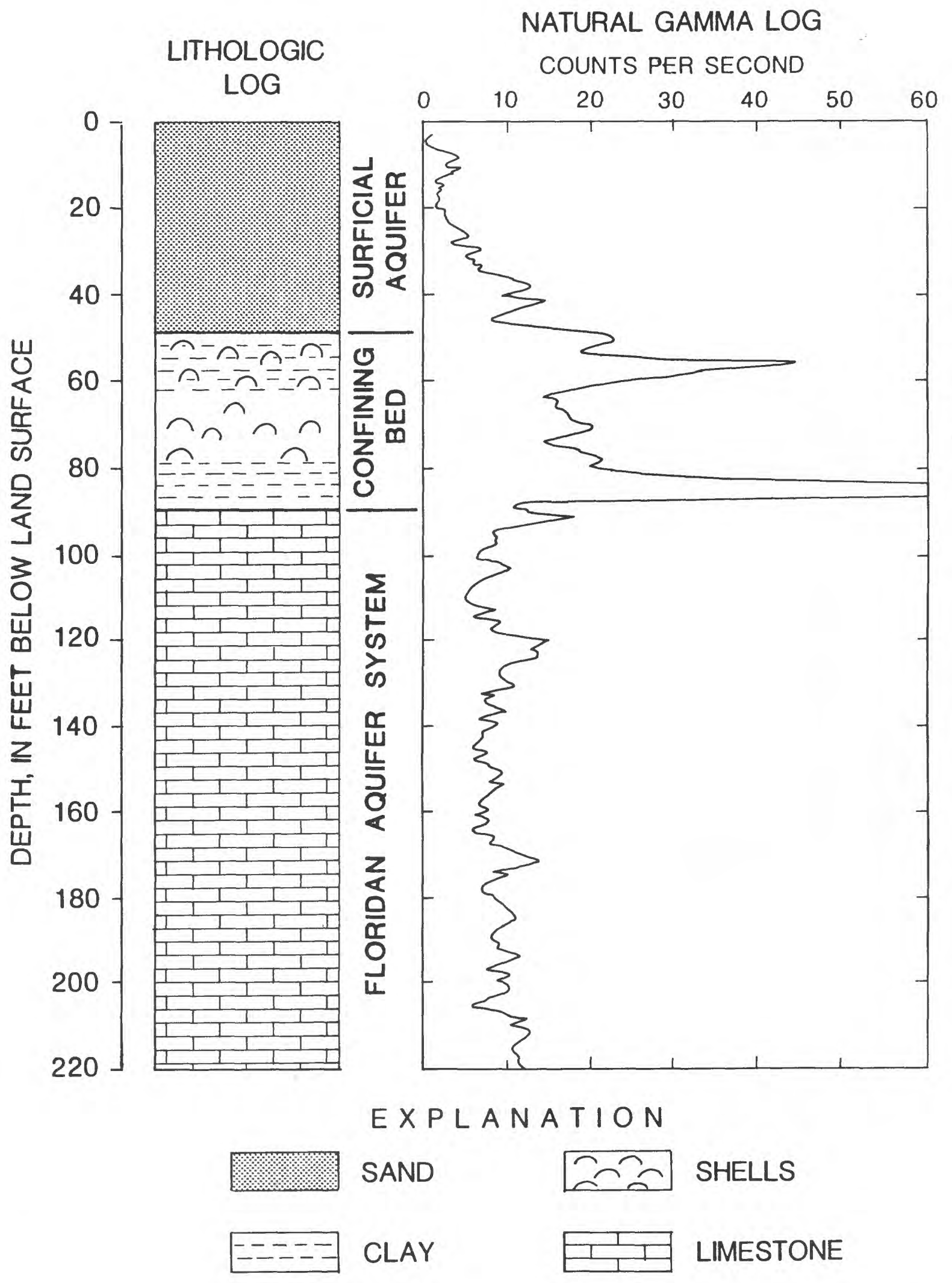

Figure 2.--Lithologic and natural gamma logs of well $2 \mathrm{~A}$. 


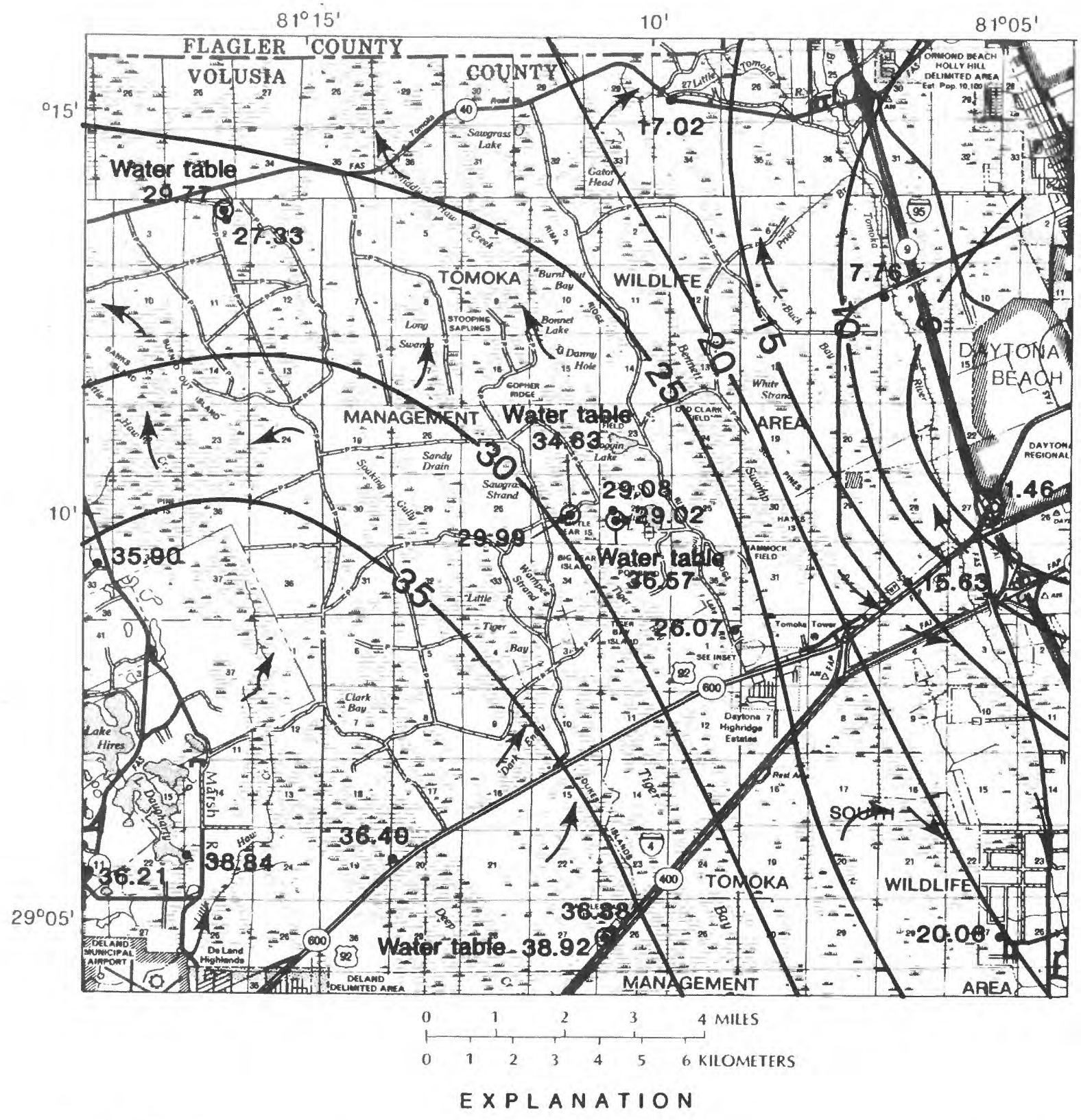

\begin{abstract}
Water
table

29.77 Number is altitude of water level

O in well, in feet above sea level.

$>$ ARROW SHOWING DIRECTION
OF SURFACE WATER FLOW
\end{abstract}

-25 - POTENTIOMETRIC CONTOUR-- Shows altitude at which water level would have stood in tightly cased wells that tap the upper part of the Floridan aquifer system, May 1978. Contour interval 5 feet. Datum is sea level.

36.40
FLORIDAN AQUIFER SYSTEM WELL-

Number is altitude of water level in well, in feet above sea level.

Figure 3.--Potentiometric surface of the upper part of the Floridan aquifer system and water levels in wells of the Floridan aquifer system and surficial aquifer, May 1978. 
North-central Volusia County is thus an area of little natural recharge to the Floridan aquifer system. However, it is part of the larger central wetlands area of Volusia County (Bush, 1978, fig. 1) that is an area of potential recharge. For example, if water were pumped from the Floridan aquifer system, the head in the Floridan aquifer system would be lowered, causing the head gradient from the surficial aquifer to the Floridan aquifer system to become greater. This greater gradient would increase downward leakage to the Floridan aquifer system until a new equilibrium is reached and the increase in recharge is equal to the pumping rate.

It is possible that the increase in downward leakage from the surficial aquifer will be equal to a decline in evapotranspiration or streamflow or both. However, this capture would involve a drawdown in the surficial aquifer. The amount of long-term drawdown that occurred in both aquifer systems during a long-term aquifer test is given in this report.

\section{PRELIMINARY TEST}

A 5-day aquifer test was conducted in January 1976 at the site of the longterm aquifer test. The purposes of this preliminary test were to determine the transmissivity, storage coefficient, and leakance coefficient of the Floridan aquifer system. The Floridan aquifer system was pumped at well $1 \mathrm{~A}$ (fig. 1) for a period of 120 hours at the rate of $1,130 \mathrm{gal} / \mathrm{min}$. Drawdown was monitored in wells in both the Floridan aquifer system and surficial aquifer.

A family of curves showing the drawdown in the Floridan aquifer system is shown in figure 4. Neither the storage coefficient nor the leakance coefficient could be ascertained. The transmissivity was determined from a curve-matching method wherein the data are superimposed on a type curve for nonsteady radial flow without leakage (Lohman, 1972). The calculated transmissivity is a function of the vertical correspondence between the data curve and the type curve. Therefore, similar transmissivities could be calculated from each of the four curves on figure 4. A match point was selected for each curve, and the values of $s$ and $W(u)$ were used to solve for transmissivity from the following equation:

$$
\mathrm{T}=\frac{\mathrm{Q}}{4 \pi \mathrm{s}} \mathrm{W}(\mathrm{u})
$$

where

$$
\begin{aligned}
& T=\text { transmissivity }\left(\mathrm{ft}^{2} / \mathrm{d}\right) ; \\
& Q=\text { discharge rate from pumping well }\left(\mathrm{ft}^{3} / \mathrm{d}\right) ; \\
& \mathrm{s}=\text { drawdown (feet); } \\
& W(\mathrm{u})=\text { the well function of } \mathrm{u} ; \text { and } \\
& \mathrm{u}=\frac{\mathrm{r}^{2} \mathrm{~S}}{4 \mathrm{Tt}}
\end{aligned}
$$

Match points for which $s=1.5$ feet and $W(u)=1.0$ were used to determine a transmissivity of approximately $12,000 \mathrm{ft}^{2} / \mathrm{d}$ (P. W. Bush, U.S. Geological Survey, oral commun., 1978). 


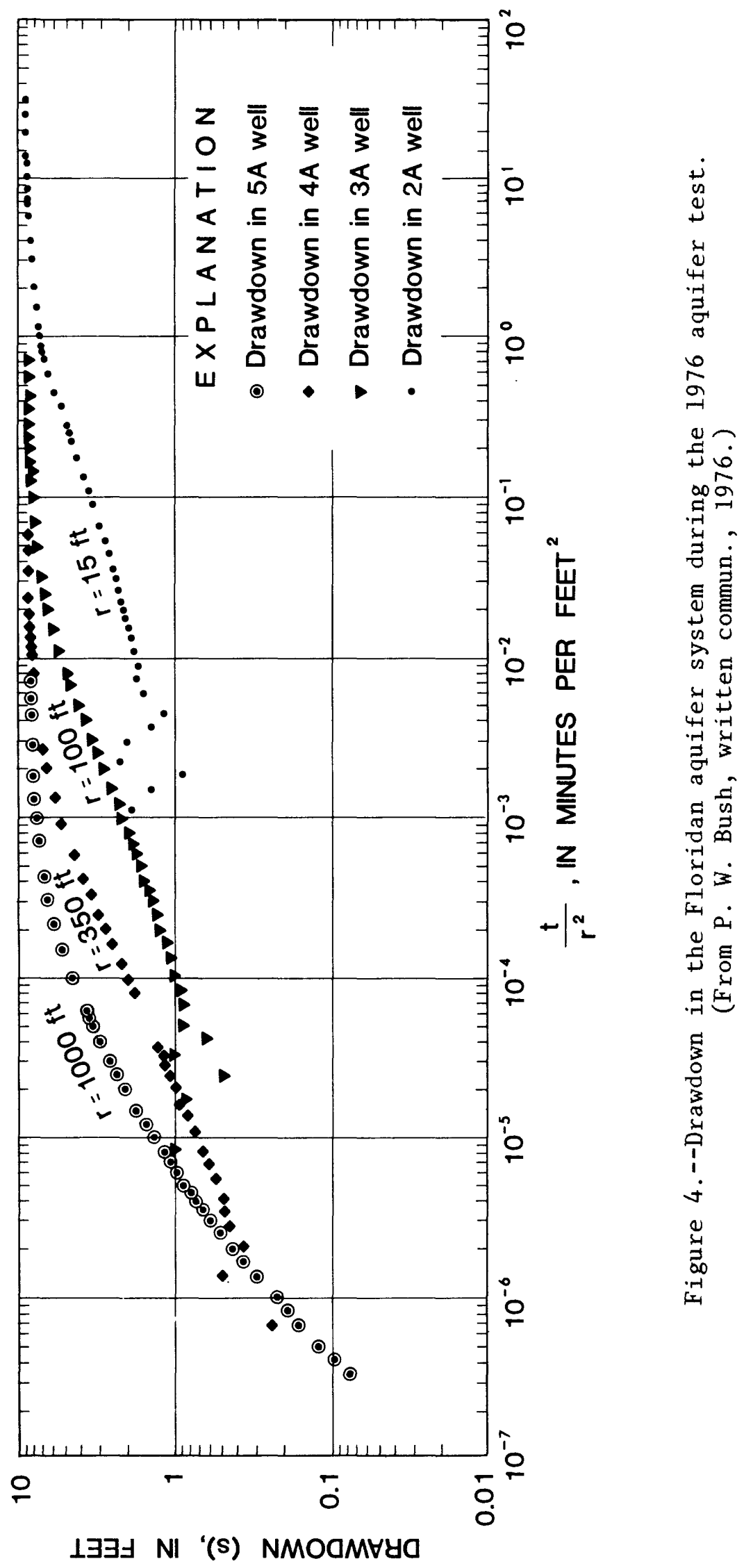


During the 5-day aquifer test in 1976, the drawdown in the Floridan aquifer system and the surficial aquifer became nearly constant. Figure 5 illustrates that when a state of equilibrium is established the ratio of the drawdown in the surficial aquifer to drawdown in the Floridan aquifer system is approximately 0.05. Of course, this drawdown ratio may vary with location. For example, the water table drawdown next to a stream or swamp may be very close to 0 . This ratio, which remains constant at a given location for different pumping rates, can be used to estimate drawdown in the water table of the surficial aquifer due to an operating well field (J. 0. Kimrey, U.S. Geological Survey, written commun., 1976). As an example, for a Floridan aquifer system drawdown of 30 feet, the drawdown in the surficial aquifer would be $0.05 \times 30$, or 1.5 feet. These estimates are limited to cases where the change in saturated thickness of the surficial aquifer is small compared to the initial saturated thickness and where water levels are in the range where evapotranspiration is reasonably approximated by a linear depth-to-water relationship.

Although drawdown appeared to have stabilized during the 5-day aquifer test, it is possible that long-term drawdown may deviate from that observed in a short test. Rainfall was 0 during the 5-day test; therefore, the hydrologic conditions during that test were unrepresentative of long-term conditons. A long-term aquifer test was needed to determine if the apparent state of equilibrium in the shorter test was in fact a steady condition.

\section{LONG-TERM AQUIFER TEST DESIGN AND DATA COLLECTION}

\section{Pumpage}

A turbine pump was installed on well lA (fig. 1) and was equipped with an electric motor and a diesel backup motor. The well was pumped from June 30 , 1978, until July 17, 1979. Pumpage averaged $560 \mathrm{gal} / \mathrm{min}$, or $0.8 \mathrm{Mgal} / \mathrm{d}$, until February 1979 after which time it averaged $500 \mathrm{gal} / \mathrm{min}$ until April 1979. During the last 3 months of the test, pumpage averaged $480 \mathrm{gal} / \mathrm{min}$. The average rate over the 382-day total period was about $530 \mathrm{gal} / \mathrm{min}$. There was a pump breakdown from January 12, 1979, to January 17, 1979, and another from January 31, 1979, to February 9, 1979. With the exception of these breakdowns, pumping was only interrupted for short maintenance periods generally lasting less than one-half hour. The water was discharged into a swamp approximately 1 mile southeast of well 1A.

\section{Data Collection}

The pumped well (well $1 \mathrm{~A}$ ) and a total of 17 other wells comprising the ground-water data collection network are shown in figure 1 and their descriptions are in table 1 . Reference to individual wells is by the well name.

Water levels in surficial aquifer wells are nearly equal to the actual water-table level. Measurements in wells in the surficial aquifer of different depths at the same location show very little head change with depth. The wells range in depth from approximately 20 to 60 feet and are completed with 2 feet of screen at the bottom. 

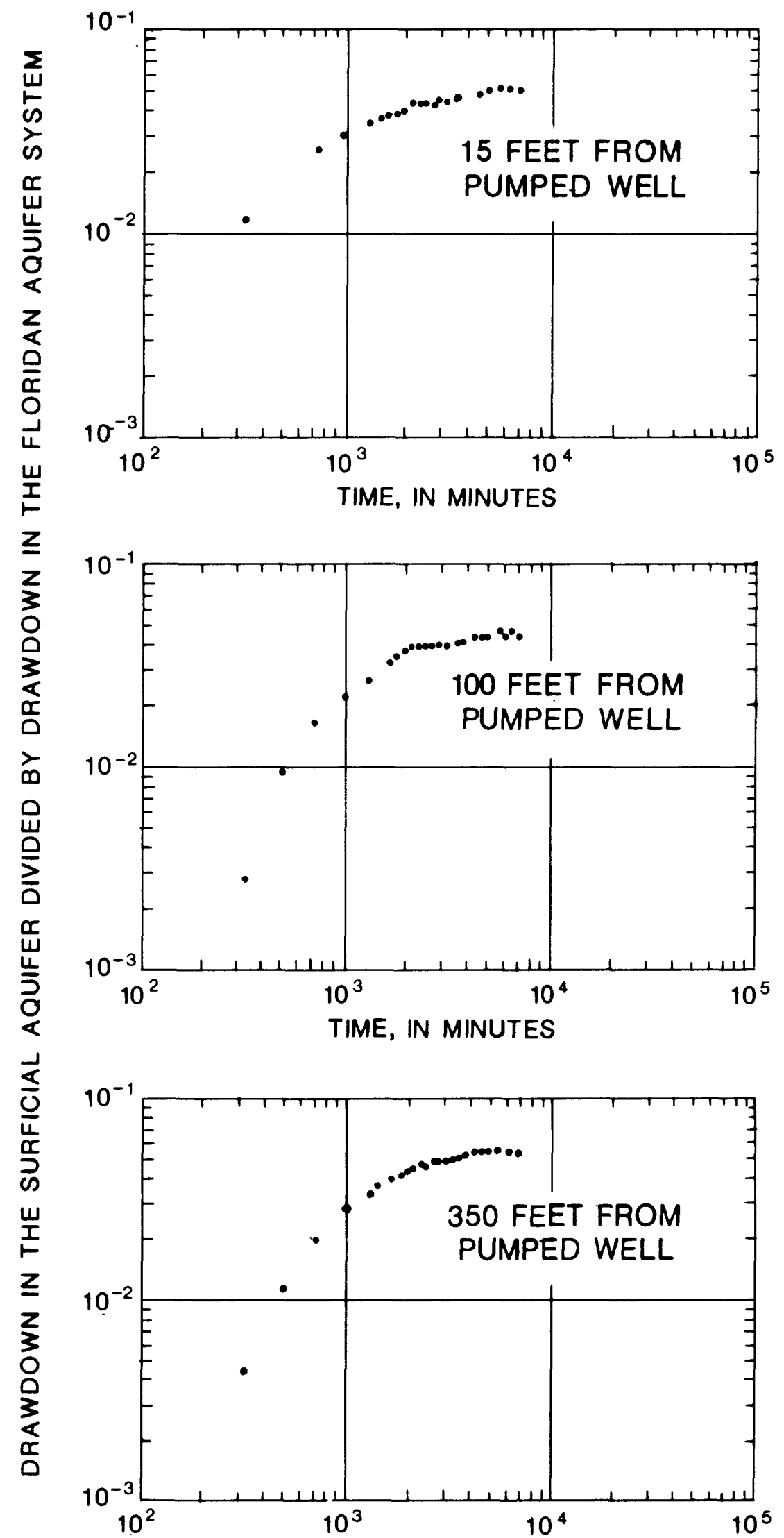

TIME, IN MINUTES

Figure 5.--Ratio of drawdown in the surficial aquifer to drawdown in the Floridan aquifer system as a function of time. (From J. 0. Kimrey, written commun., 1976, on 1976 aquifer test.) 


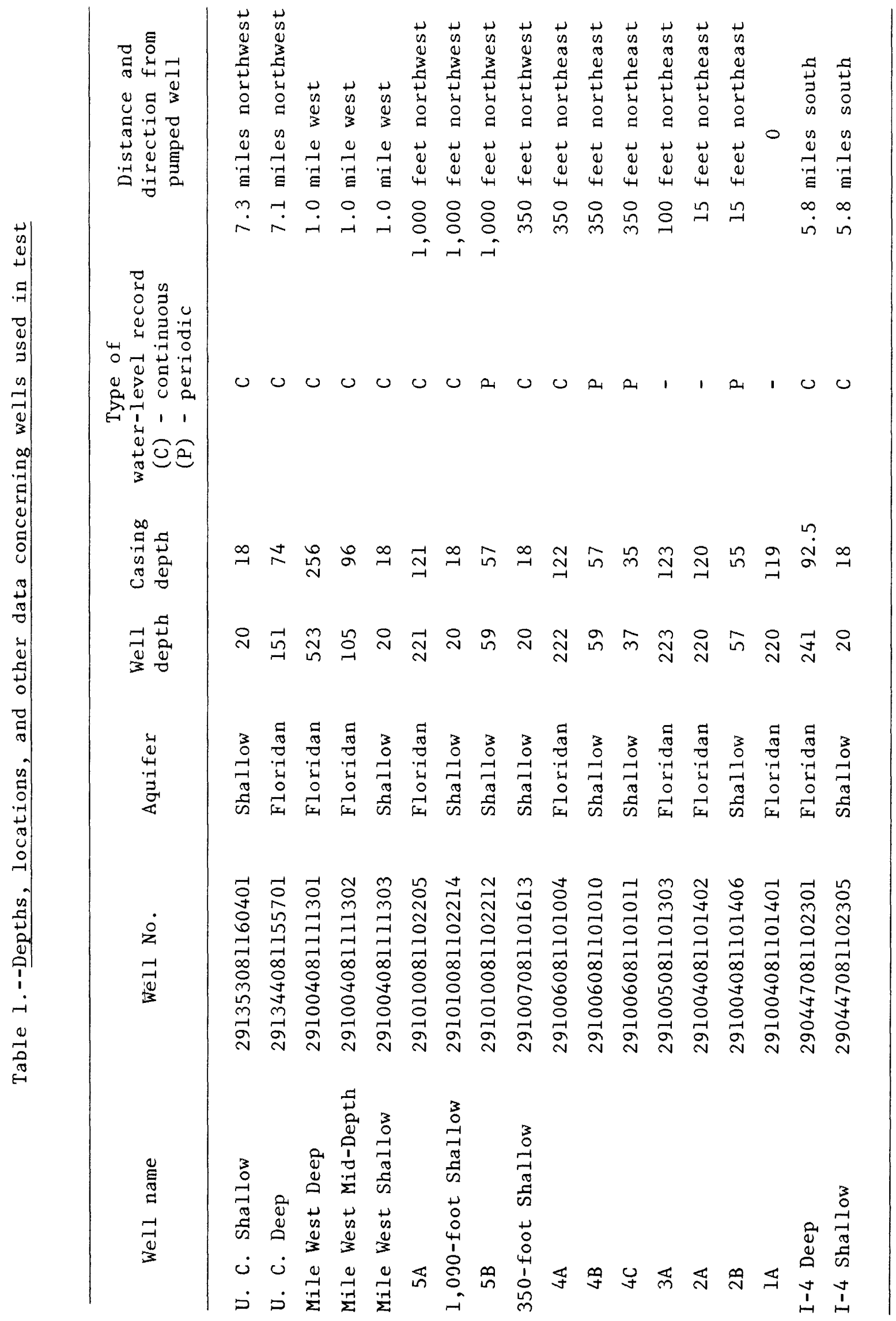


With the exception of Mile West Deep, which is cased more than 100 feet into the limestone, all wells in the Floridan aquifer system, including the pumped well, are cased only to the top of rock, which is about 100 feet below land surface, then completed as open holes in the rock formation down to 150 to 220 feet. These wells are open to the upper part of the Floridan aquifer system, the zone which was subjected to pumping stress during the test. Mile West Deep is cased to 256 feet and is an open hole to a depth of 523 feet. It is, therefore, open to a deeper unstressed zone in the Floridan aquifer system.

Water-level data were collected before, during, and after the pumping period at nine wells in the surficial aquifer and six wells in the Floridan aquifer system (table 1). Water-level recorders were used to monitor levels in six wells in the Floridan aquifer system and in five wells in the surficial aquifer. Periodic tape measurements were made in the four wells in the remaining surficial aquifer. Most water-level recorders were operational from April 1978 to November 1979 whereas some were operational until October 1980. Four water-level recorders were still operational as of the date of this publication (1985): U. C. Shallow, U. C. Deep, 350-foot Shallow, and 4A. Three rainfall recorders were maintained during the test.

\section{DESCRIPTION OF DOUBLE-MASS CURVES}

Double-mass curves are used to separate the drawdown caused by pumping from the "noise" in the water-level data caused by natural water-level fluctuations. The theory is that a graph of cumulation of one quantity against the cumulation of another quantity during the same period will plot as a straight line as long as the two quantities are proportional. A break in the slope of the double-mass curve means that a change in the constant of proportionality between the two variables has occurred. The difference in the slope of the lines indicates the degree of change in the relation (Searcy and Hardison, 1960).

Drawdown is defined as the difference between the water level in a well and the water level that would have existed in that well if pumping had not occurred. The difficulty of observing drawdown is demonstrated by an example in which the natural water level trend is a rapid ascent and in which the waterlevel decline because of pumping (drawdown) is not large enough to cause the water level to decline. In this example, the water level actually increases during the period of pumping. In order that drawdown may be determined, the fluctuations caused by factors other than pumping must be removed from the data.

The double-mass curves were constructed with the corresponding cumulative daily water levels from (1) a test well in which drawdown was expected, and (2) a control well in which little or no drawdown was expected. The data were plotted with the test well as the vertical axis and the control, or unaffected, well as the horizontal axis (fig. 6). Drawdown may be determined graphically by the method outlined in the figure. This method is valid only if the drawdown reaches a state of equilibrium before the time period represented by segment $B-B^{\prime}$. Therefore, the segment $B-B^{\prime}$ in figure 6 must have a uniform slope. The segment must not exhibit a gradually decreasing slope from point $B$. to point $B^{\prime}$, because this would indicate that drawdown had not reached a state of equilibrium before the $\mathrm{B}^{-\mathrm{B}^{\prime}}$ time period. 


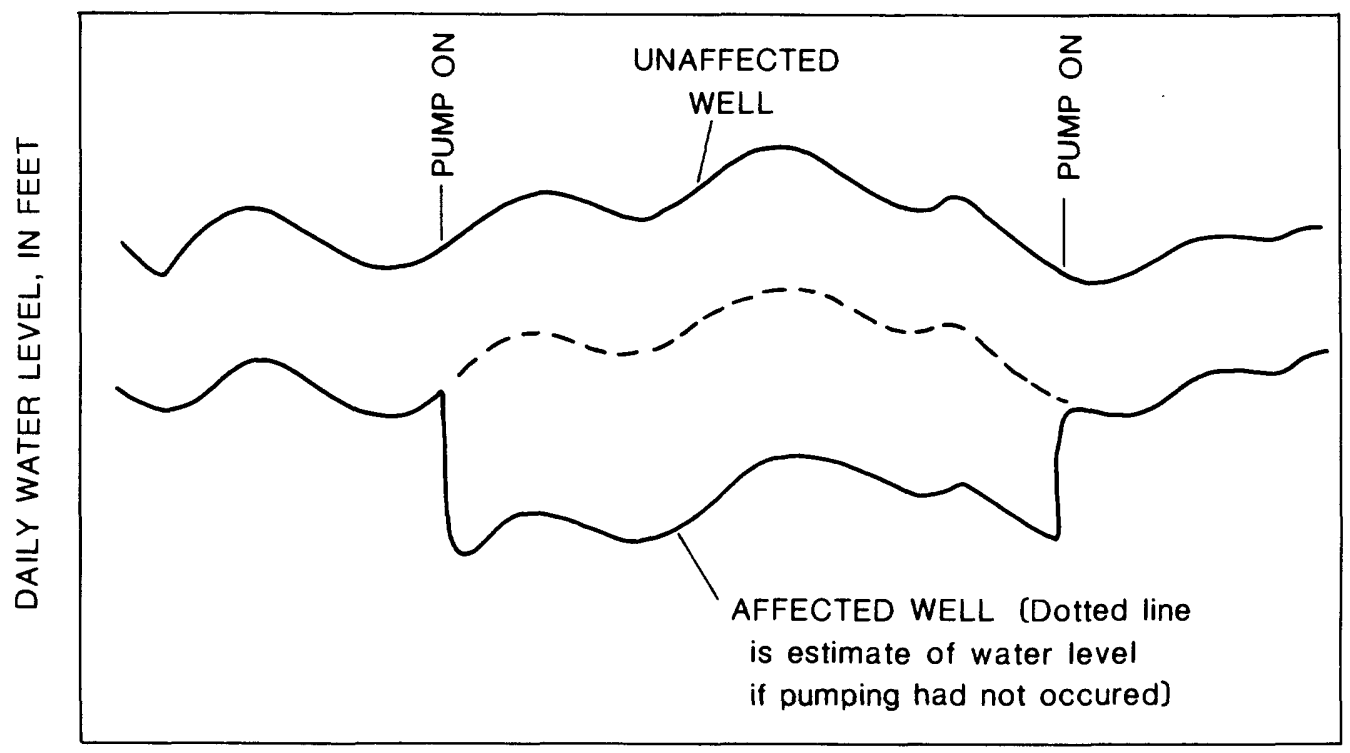

TIME

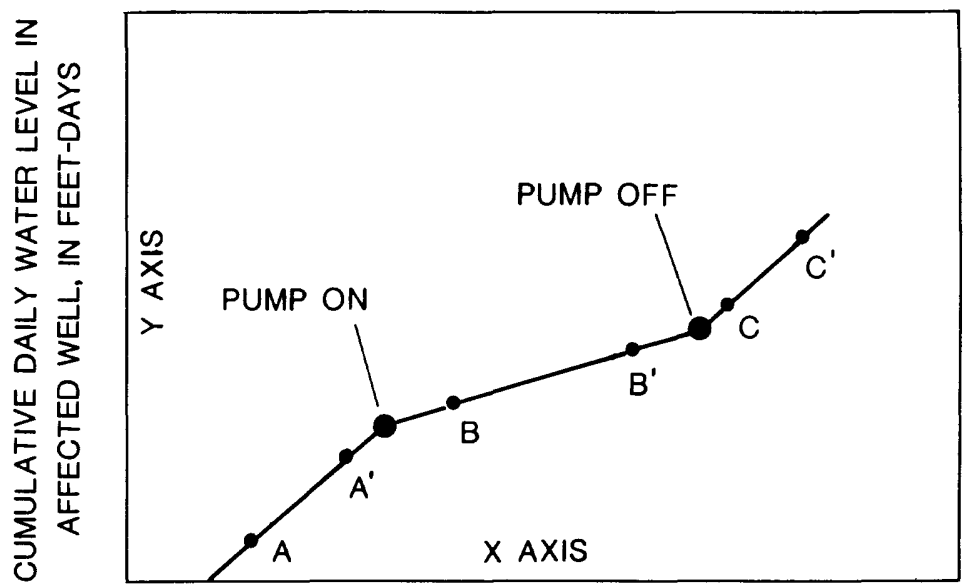

CUMULATIVE DAILY WATER LEVEL IN

UNAFFECTED WELL, IN FEET-DAYS

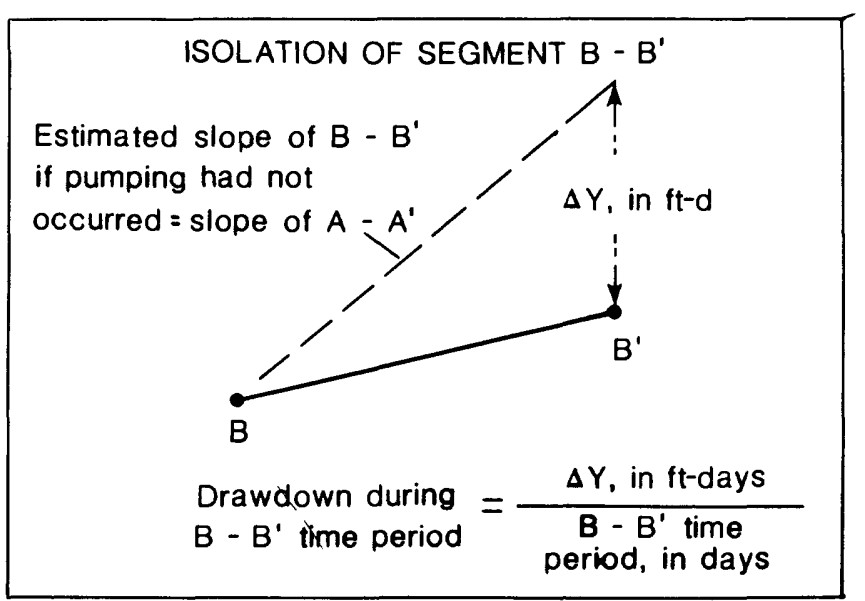

Figure 6.--Idealized hydrograph and double-mass curve showing the water-level record in observation wells before, during, and after a period of pumping from another well. 
If changes in slope are very slight, or if greater accuracy is required, it is necessary to calculate drawdown by mathematical methods. The following equation is used to determine drawdown:

$$
s_{B^{-} B^{\prime}}=\frac{\frac{\left(X_{B^{\prime}}-X_{B}\right)\left(Y_{A^{\prime}}-Y_{A}\right)}{\left(X_{A^{\prime}}-X_{A}\right)}-\left(Y_{B^{\prime}}-Y_{B}\right)}{t_{B-B^{\prime}}}
$$

where

$$
\begin{aligned}
s_{B-B^{\prime}}= & \text { drawdown during the time period } B^{-} B^{\prime} \text {, in feet; and } \\
t_{B-B^{\prime}=} & \text { time period represented by the segment } B-B^{\prime} \text {, in days, and other } \\
& \text { variables are the } X-\text { and } Y-\text { coordinates of the endpoints of } \\
& \text { line segments on double-mass curves, in feet-days. }
\end{aligned}
$$

Figure 6 and the accompanying discussion are based on an idealized representation. However, a double-mass curve drawn from field data may show changes in slope that are caused by factors other than pumping. This state of nonproportionality may exist, for example, because the natural water-level decline or rise for a given period may be larger in one well than in another. Because of these differences, the change in slope caused by pumping alone may be less discernible. Other errors could arise if the nonstress time period is not long enough. This period must be of great enough length such that proportionality can be demonstrated.

The cumulative daily water levels used for double-mass curves are above datums chosen such that the maximum water levels are approximately 50 percent greater than the minimum water levels. This choice of datums was made to increase the sensitivity and to maximize the proportionality of the doublemass curves. The intent of this is to make it possible to closely approximate the water level at one site by a constant times the water level at another site. The datum for each well record is:

\begin{tabular}{lclc}
\hline Well & $\begin{array}{c}\text { Altitude } \\
\text { (in feet) }\end{array}$ & \multicolumn{1}{c}{ Well } & $\begin{array}{c}\text { Altitude } \\
\text { (in feet) }\end{array}$ \\
\hline U. C. Shallow & 15 & 350 -foot Shallow & 30 \\
U. C. Deep & 20 & 1,000 -foot Shallow & 30 \\
Mile West Deep & 21 & 4 A & 21 \\
Mile West Middepth & 21 & I-4 Deep & 31 \\
Mile West Shàllow & 26 & I-4 Shallow & 35 \\
\hline
\end{tabular}


This is only one method of choosing datums. Other methods could be employed to increase proportionality. Of greatest importance is that a given procedure is applied uniformly for all water-level records.

\section{RESPONSE IN THE FLORIDAN AQUIFER SYSTEM}

The drawdown at well 4A, which is 350 feet from the pumped well, is obvious in the graphic plot (fig. 7). Drawdown of water levels at the beginning of pumping and recovery at the end are approximately 3.5 to 4.5 feet for each pumping period.

The water-level fluctuations of three other wells in the Floridan aquifer system show the same general fluctuations as $4 \mathrm{~A}$ except for obvious drawdown (fig. 7). The 4A record parallels that of U. C. Deep before and after pumping but also parallels it during pumping at a different vertical position. The U. C. Deep and the I-4 Deep record show little or no effect of pumping, whereas the Mile West Middepth shows a small effect which is noticeable because of pump failures. The U. C. Deep and I-4 Deep records may therefore be used as control wells for assessing drawdown in the other two wells.

Figure 8 is a double-mass curve in which $4 \mathrm{~A}$ is the test well and $\mathrm{U}$. C. Deep is the control well. The effects of pumping are shown here in a way that is similar to the idealized double-mass curve of figure 6 . The plot departs from the idealized double-mass curve because of discontinuous pumpage. The pump failures of January to February 1979 cause temporary returns to the nonpumping slope. The slope after the pump failures is greater than it is before the failures because the pumping rate decreased from $560 \mathrm{gal} / \mathrm{min}$ before failures to as low as $480 \mathrm{gal} / \mathrm{min}$ after failures. January 11, 1979, as indicated in figure 8 , preceded the first pump failure by one day.

The drawdown at well 4A may be calculated for a period of time that preceded the pump failures using segments $B-B^{\prime}, C-C^{\prime}$, and $D^{\prime}-D^{\prime}$, and may also be calculated for a period of time after the pump failures using segment $E_{-} E^{\prime}$. For each of these calculations, the segment A-A' is used as a reference. Therefore, the calculated drawdowns are 4.5 feet for segment B-B', 4.6 feet for segment $C-C^{\prime}, 4.0$ feet for segment $D^{\prime} D^{\prime}$, and 3.6 feet for segment $E-E^{\prime}$. The average drawdown for the pumping period up to January 11, 1979, is approximately 4.3 feet.

The average drawdown at well 5A during the part of the pumping period to January 11, 1979, is estimated as 4.1 feet. The basis for this estimate is that the water level in well $5 \mathrm{~A}$ was 0.2 foot higher than that of $4 \mathrm{~A}$ during the period of June 30,1978 , to January 11, 1979, yet levels in the two wells were essentially equal before the pumping began.

The double-mass curve of Mile West Middepth versus U. C. Deep has a noticeable break in the slope at the time the pump was turned on (fig. 9). The calculated drawdowns are: 1.0 foot for segment B-B', 1.4 feet for segment $C-C^{\prime}, 0.7$ foot for segment $D^{-D^{\prime}}$, and 0.6 foot for segment E-E'. The average drawdown for the pumping period up to January 11, 1979, is approximately 1.0 foot. 


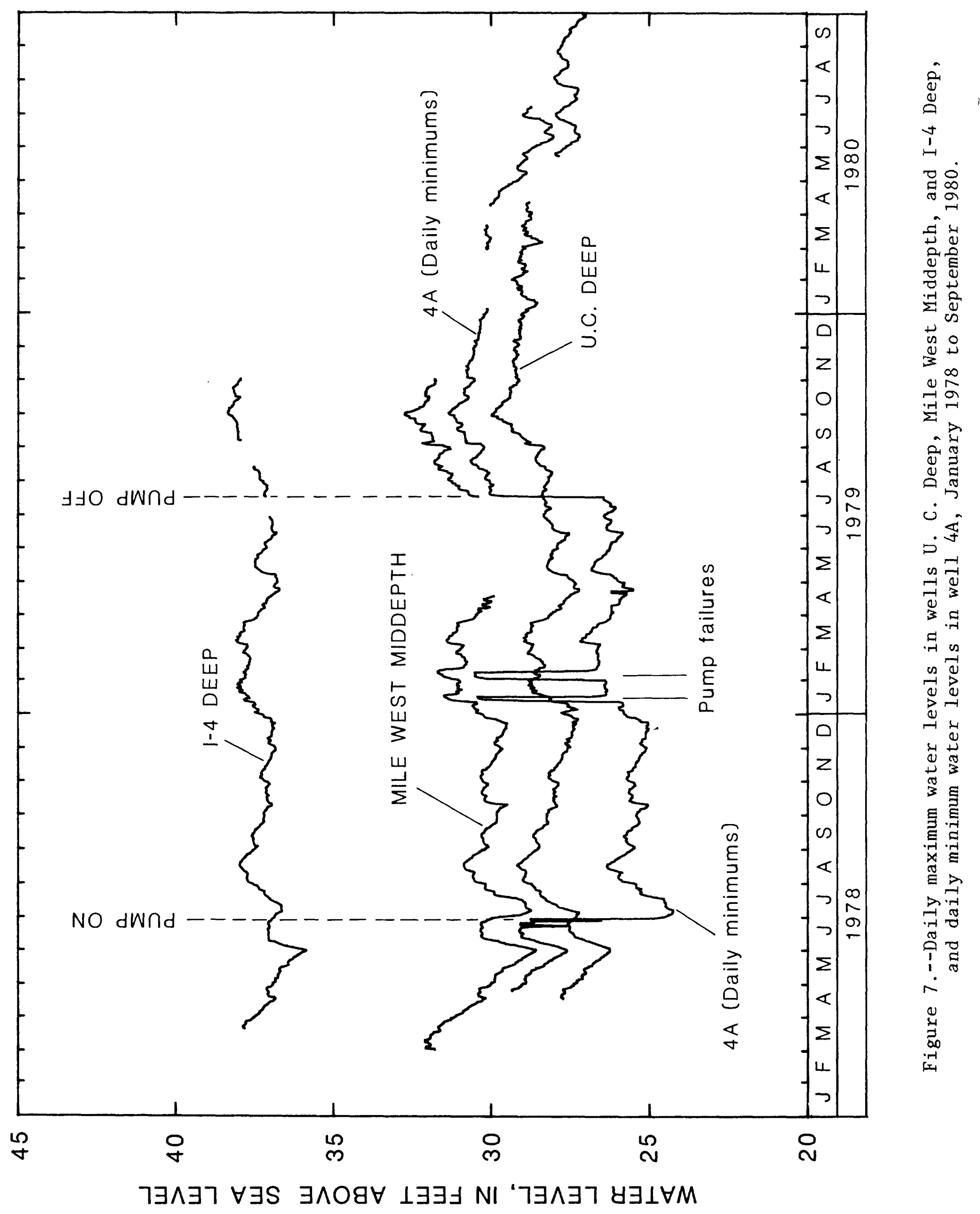




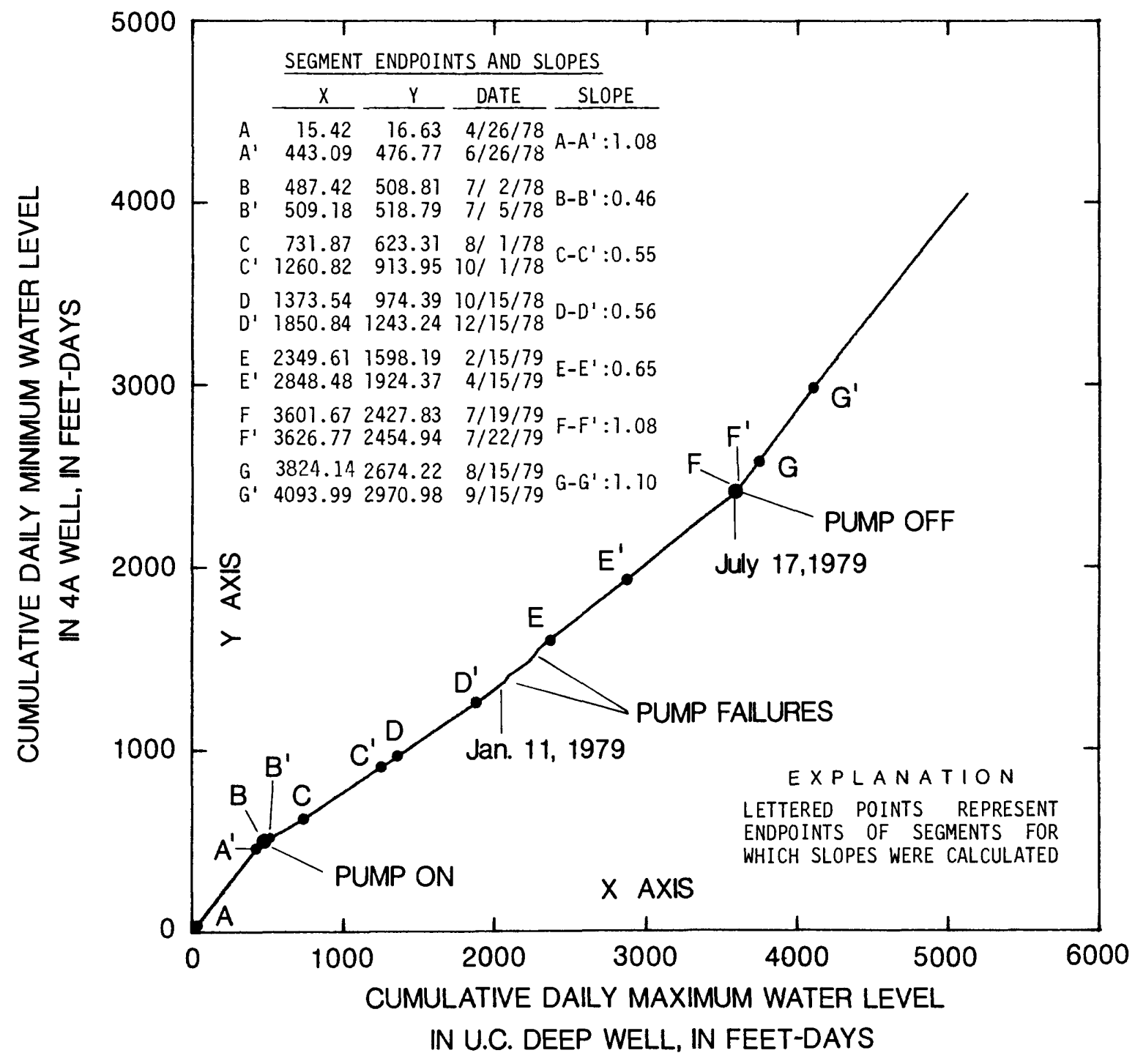

Figure 8.--Double-mass curve of water-level data for $4 \mathrm{~A}$ well and U. C. Deep well for the period April 25, 1978 to January 4, 1980. 


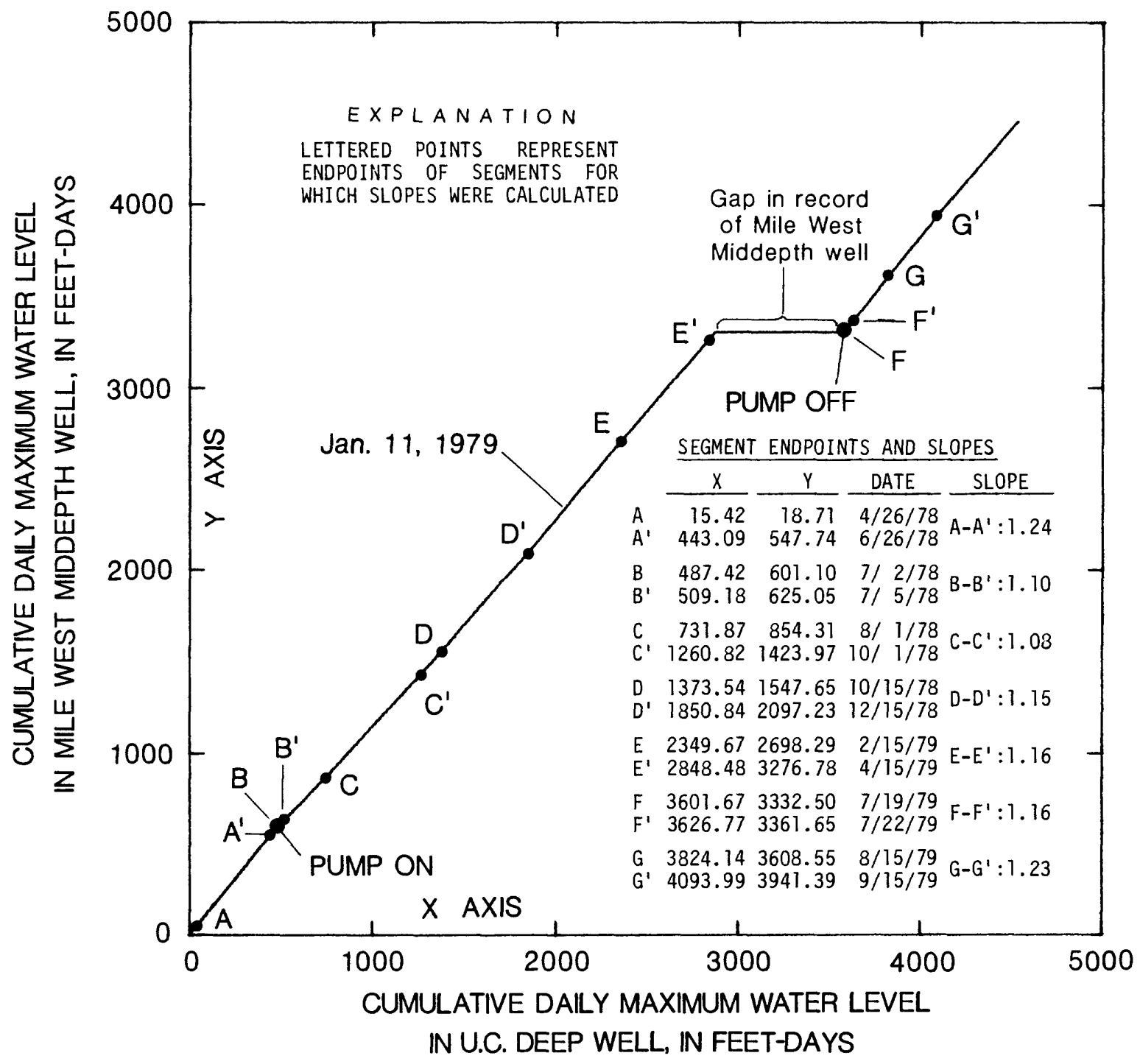

Figure 9.--Double-mass curve of water-level data for Mile West Middepth well and U. C. Deep well for the period April 25, 1978 to October 31, 1979. 
The change in slope in figure 10 at the time the pump was turned on indicates that I-4 Deep is also affected. The calculated drawdowns are 0.1 foot for segment $B^{-} B^{\prime}, 0.5$ foot for segment $C-C^{\prime}, 0.3$ foot for segment $D-D^{\prime}$, and 0.2 foot for segment E-E'. The average drawdown for the period up to January 11, 1979, is approximately 0.4 foot.

If I-4 Deep had drawdown, then it is possible that U. C. Deep may also have been affected. U. C. Deep is only 1.3 miles farther from the production well than I-4 Deep. In view of this possible drawdown, the drawdowns calculated in other wells by double-mass curve analysis using U. C. Deep as the control should be described as "the amount of drawdown in excess of the drawdown at U. C. Deep" instead of using absolute terminology.

\section{RESPONSE IN THE SURFICIAL AQUIFER}

Figure 11 shows the water-level record of the 350-foot Shallow well along with the record of 4A. These wells are the same distance from the pumped well. A slight drawdown of 0.1 to 0.2 foot in the shallow well is indicated by a break in slope on the hydrograph when the pump was turned on. However, the drawdown is so small that, on the long-term basis, it cannot be separated from the "noise" in the data caused by natural water-level fluctuations. It is for this reason that double-mass curve analysis is especially useful for assessing drawdown in the surficial aquifer.

Fluctuations of the water table at four different sites are shown in figure 12. Because of its location, U. C. Shallow was used as a control well. Mile West Shallow was also used as a control well because of the greater similarity between the natural fluctuations of water level at that well and the natural fluctuations of water levels at the test well. However, water levels at Mile West Shallow may be slightly affected. For double-mass curves, 1,000-foot Shallow is shown instead of 350-foot Shallow because, unlike the 350-foot Shallow record, the 1,000-foot Shallow record was uninterrupted during the pumping period and continued uninterrupted for a relatively long period after the pump was turned off.

Very little drawdown at 1,000-foot Shallow well is detectable on the double-mass curve in figure 13. The average slope for the period of pumping is 0.46 .

It is possible that slope changes caused by drawdown can be separated from those caused by nonproportionalities in records if double-mass curves from affected wells are compared to double-mass curves from wells less affected. The slope changes in figure 13 are similar to those in figure 14, although Mile West Shallow well is less affected than 1,000-foot Shallow well. The data from these double-mass curves, in addition to two others not shown, may be compared because U. C. Shallow well is used as the control well for all and because the lettered points represent the same day for all with the exception of point $G^{\prime}$ : 


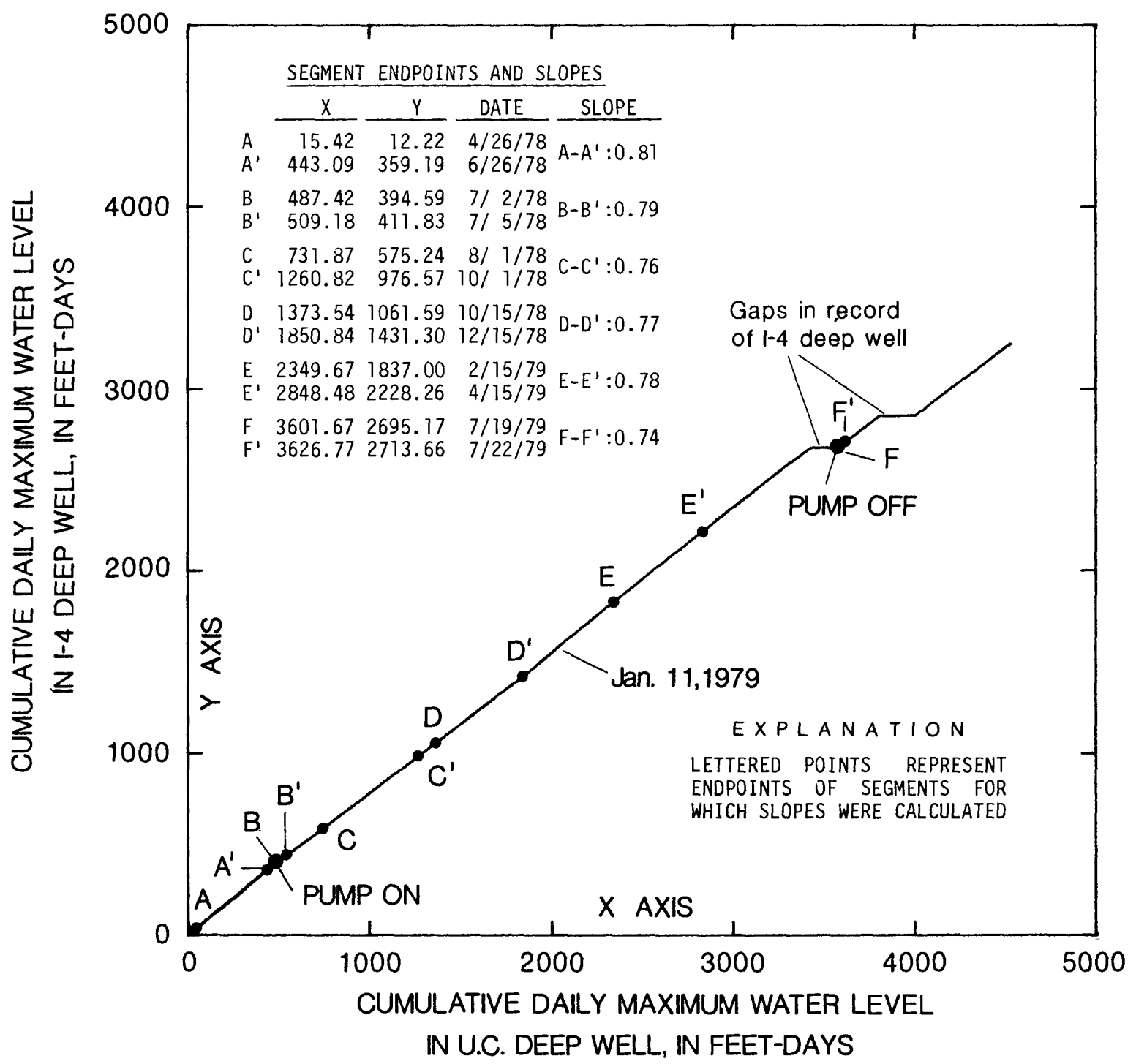

Figure 10.--Double-mass curve of water-level data for I-4 Deep well and U. C. Deep well for the period April 25, 1978 to October 31, 1979. 


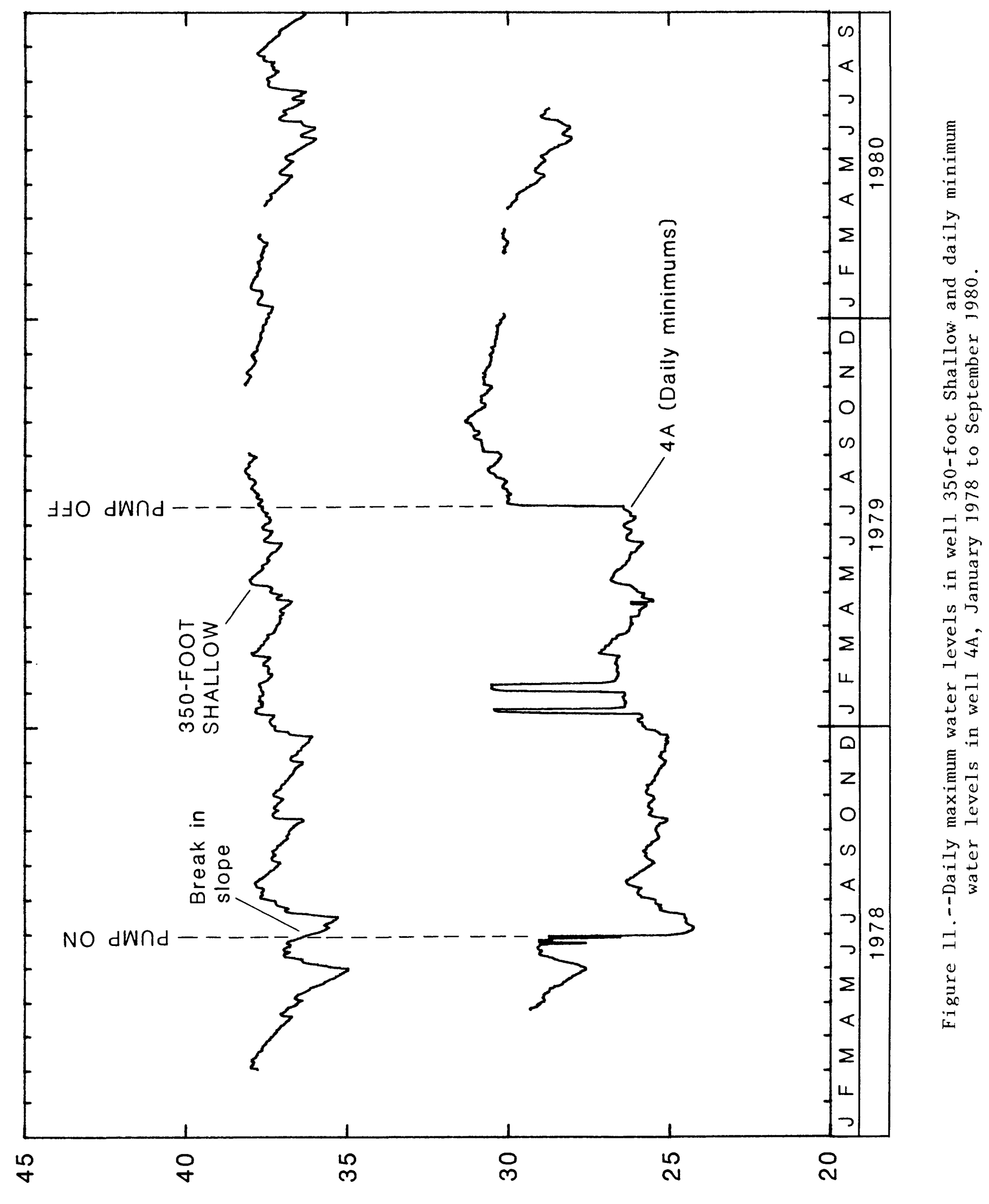

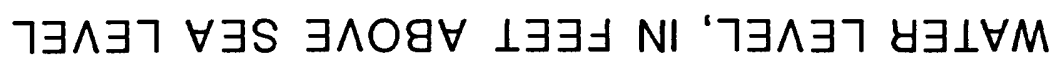




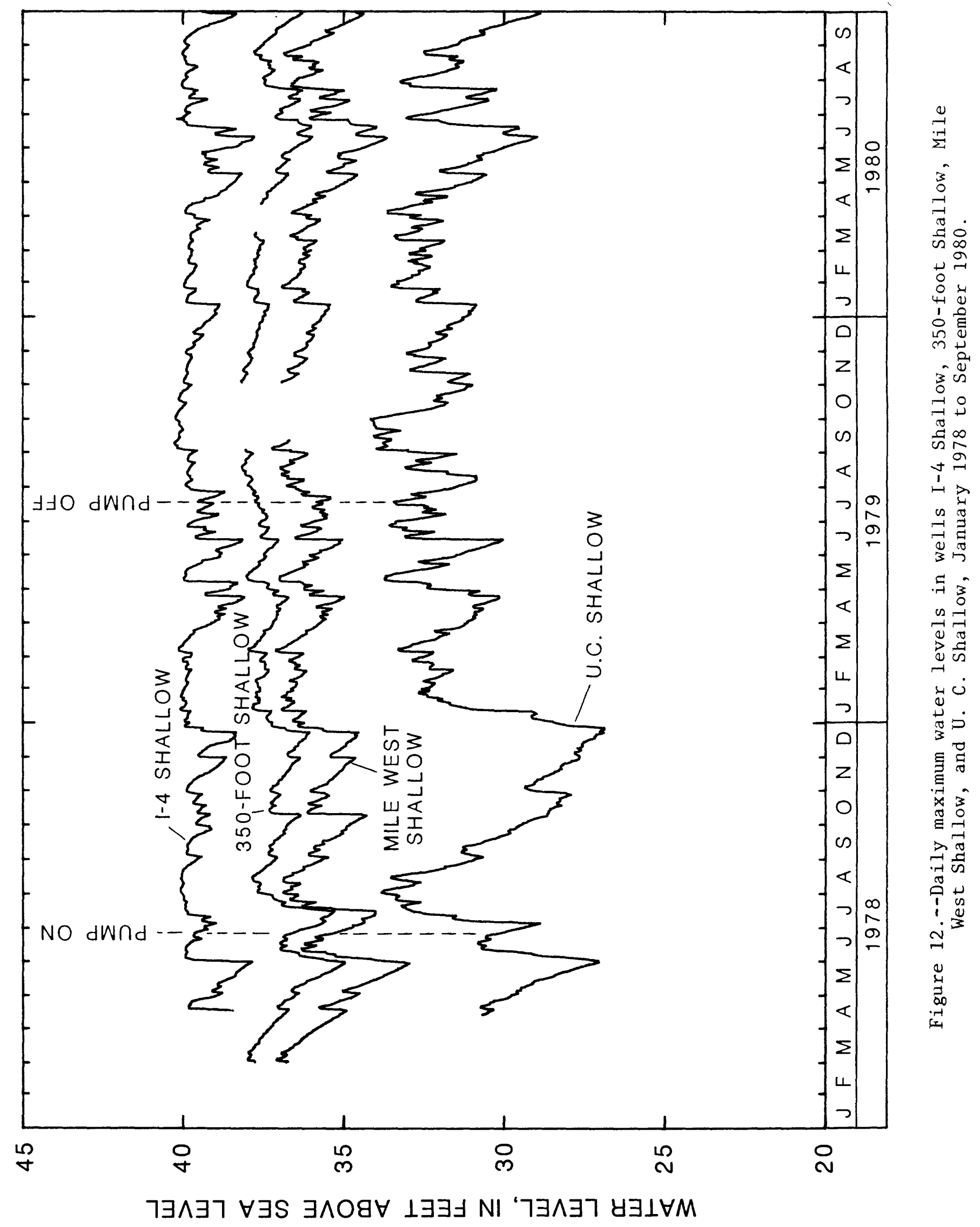




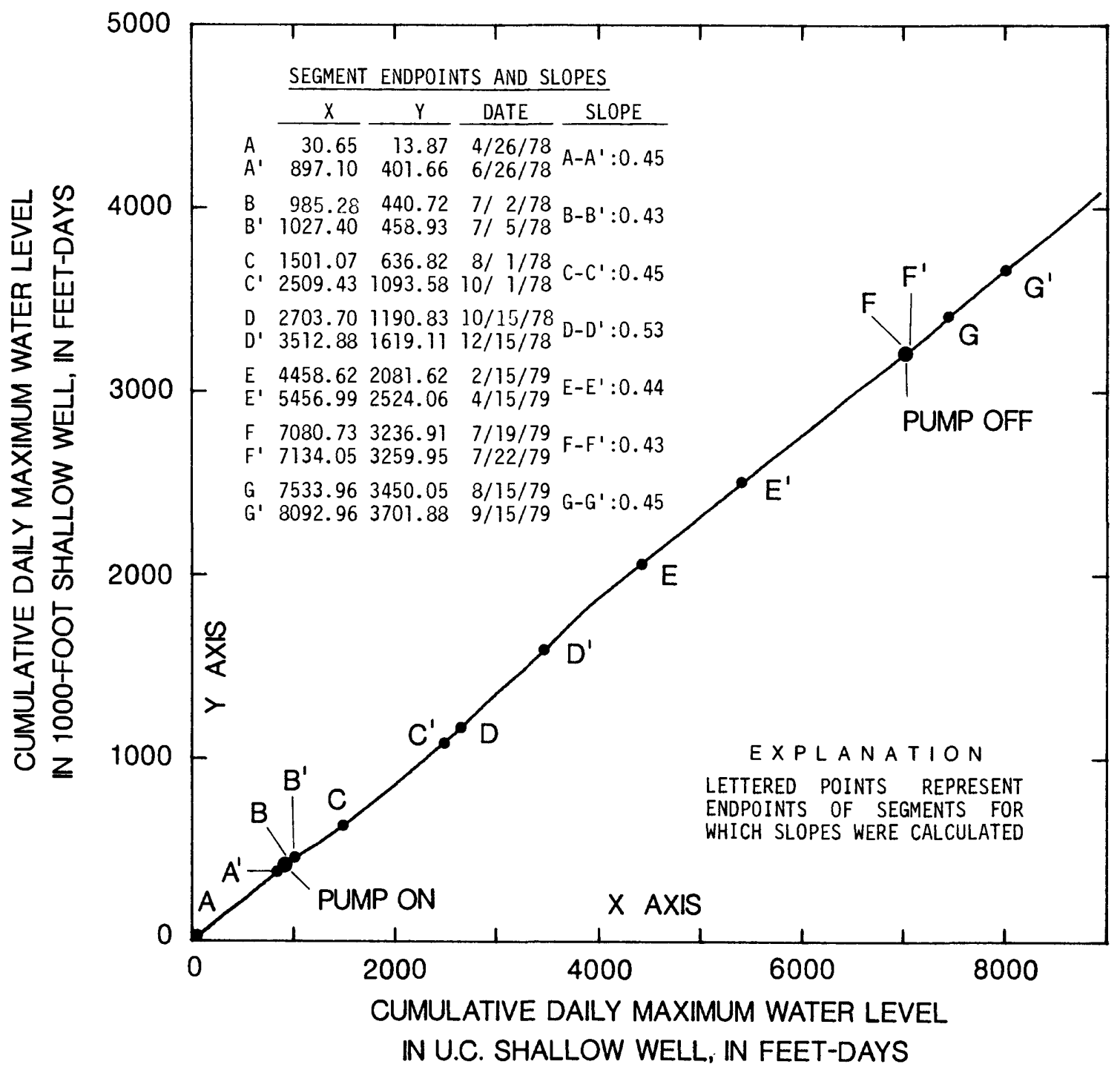

Figure 13.--Double-mass curve of water-level data for 1,000-foot Shallow well and U. C. Shallow well for the period April 25, 1978 to November 1, 1979. 


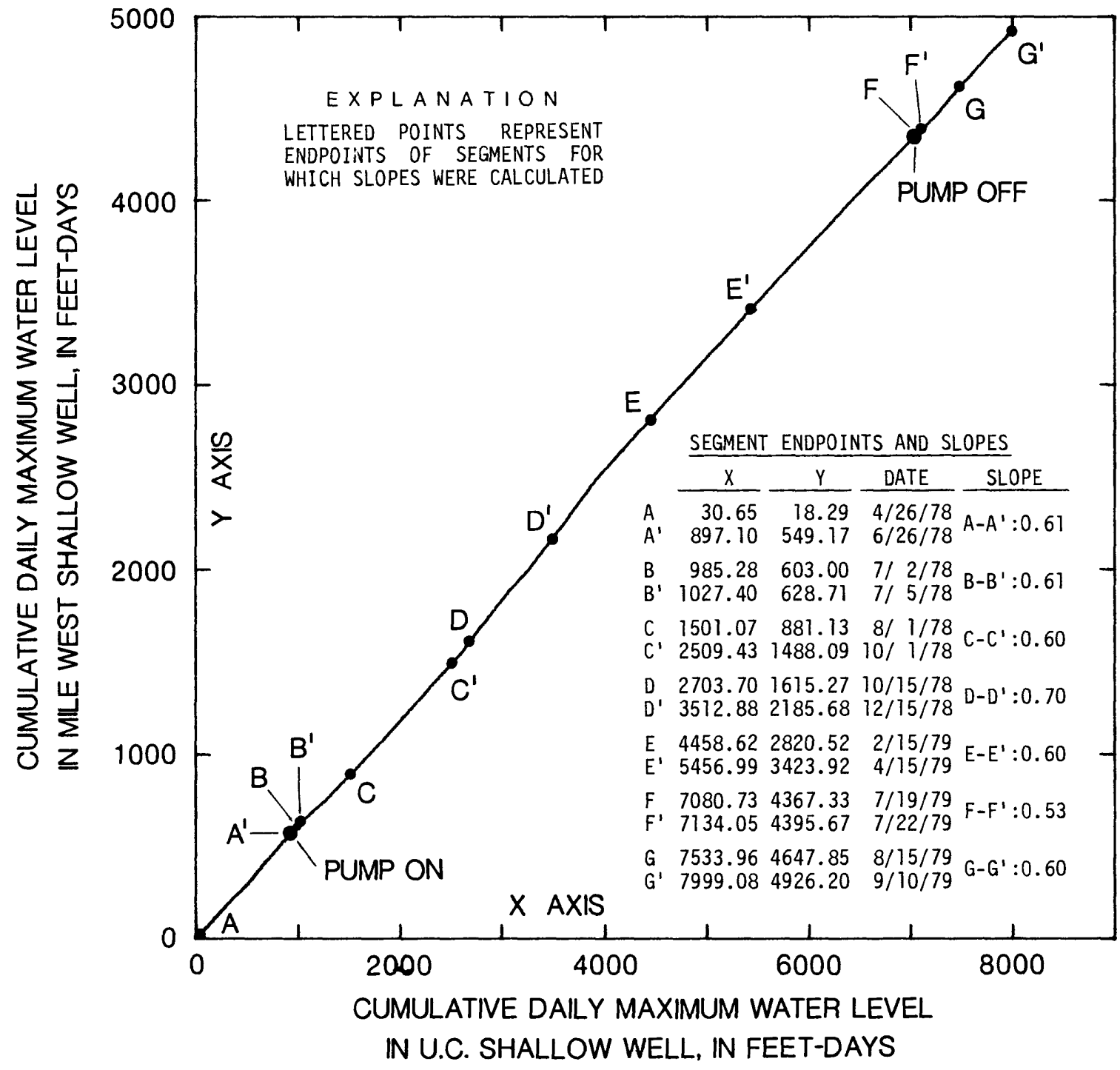

Figure 14.--Double-mass curve of water-level data for Mile West Shallow well and U. C. Shallow well for the period April 25, 1978 to September 10, 1979. 


\begin{tabular}{ccccc}
\hline Segment & $\begin{array}{c}350-\mathrm{ft} \\
\text { Shallow } \\
\text { well }\end{array}$ & $\begin{array}{c}\text { 1,000-ft } \\
\text { Shallow } \\
\text { well }\end{array}$ & $\begin{array}{c}\text { Mile West } \\
\text { Shallow } \\
\text { well }\end{array}$ & $\begin{array}{c}\text { I-4 } \\
\text { Shallow } \\
\text { well }\end{array}$ \\
\hline A-A $^{\prime}$ & 0.44 & 0.45 & 0.61 & 0.29 \\
B-B' & .41 & .43 & .61 & .29 \\
C-C' & .44 & .45 & .60 & .29 \\
D-D' & .52 & .53 & .70 & .33 \\
E-E' & -- & .44 & .60 & .27 \\
F-F' & .43 & .43 & .53 & .24 \\
G-G' & -- & .45 & .60 & .27 \\
\hline
\end{tabular}

The general similarity between the slope changes of each record indicates that most of the slope changes are caused by slight nonproportionalities between water-level records and not by pumping. There is an increase in slope in segment $D^{-D^{\prime}}$ for all four records. This seems to be related to natural water-level changes and must not be associated with pumping, because the change is approximately equal for all. There is a reduction in slope from $A_{-} A^{\prime}$ to $B-B^{\prime}$ for 350-foot Shallow and for 1,000-foot shallow but not for the other two. This may be caused by drawdown at these wells much closer to the pumping well. Apparently, the only slope anomaly in figure 13 that is caused by pumping is that exhibited by segment $B-B^{\prime}$. It is apparent from the change in slope from $B-B^{\prime}$ to $C-C^{\prime}$ in figure 13 that any initial drawdown at 1,000-foot Shallow was counteracted by a recovery and that the long-term drawdown at that site was probably less than the 0.2 -foot initial drawdown.

The double-mass curve of 1,000-foot Shallow versus Mile West Shallow (fig. 15) shows the same temporary decline in slope immediately after the beginning of pumping that is apparent on curves using $U$. C. Shallow as the control well. Segment $B-B^{\prime}$ has an anomalously low slope.

Double-mass curves show that the water-level records for wells in the surficial aquifer are considerably less proportional to each other than records of wells in the Floridan aquifer system are to each other. One reason for this may be that the surficial aquifer levels are more immediately affected by rainfall. On a short-term basis, areally unequal rainfall may cause a water-level increase at one well whereas another well exhibits no change. The Floridan aquifer system levels, however, are influenced by rainfall trends over a larger time period, and short-term differences in rainfall tend to even out.

Figure 16, which is a double-mass curve of rainfall data for the East rain gage and the Mile West rain gage, has slope changes that are similar to those in figure 15. For example, segment $C-C^{\prime}$ exhibits greater slopes than segments $A^{-} A^{\prime}$ and $E-E^{\prime}$ in both figure 15 and figure 16. This supports the idea that most slope changes on these double-mass curves of water-level data are caused by areal variations in the rainfall rate. 


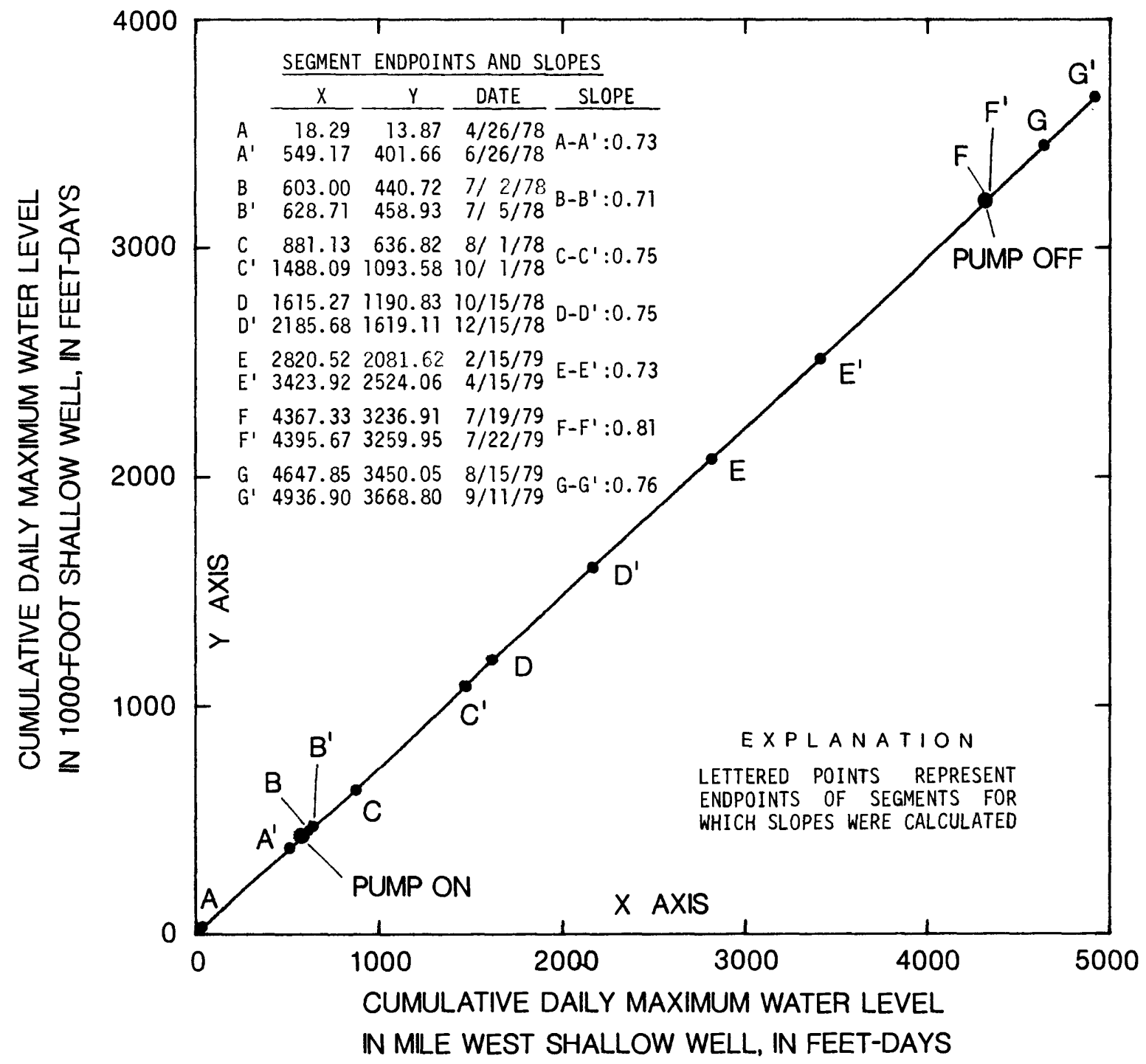

Figure 15.--Double-mass curve of water-level data for 1,000-foot Shallow well and Mile West Shallow well for the period April 25, 1978 to September 11, 1979. 


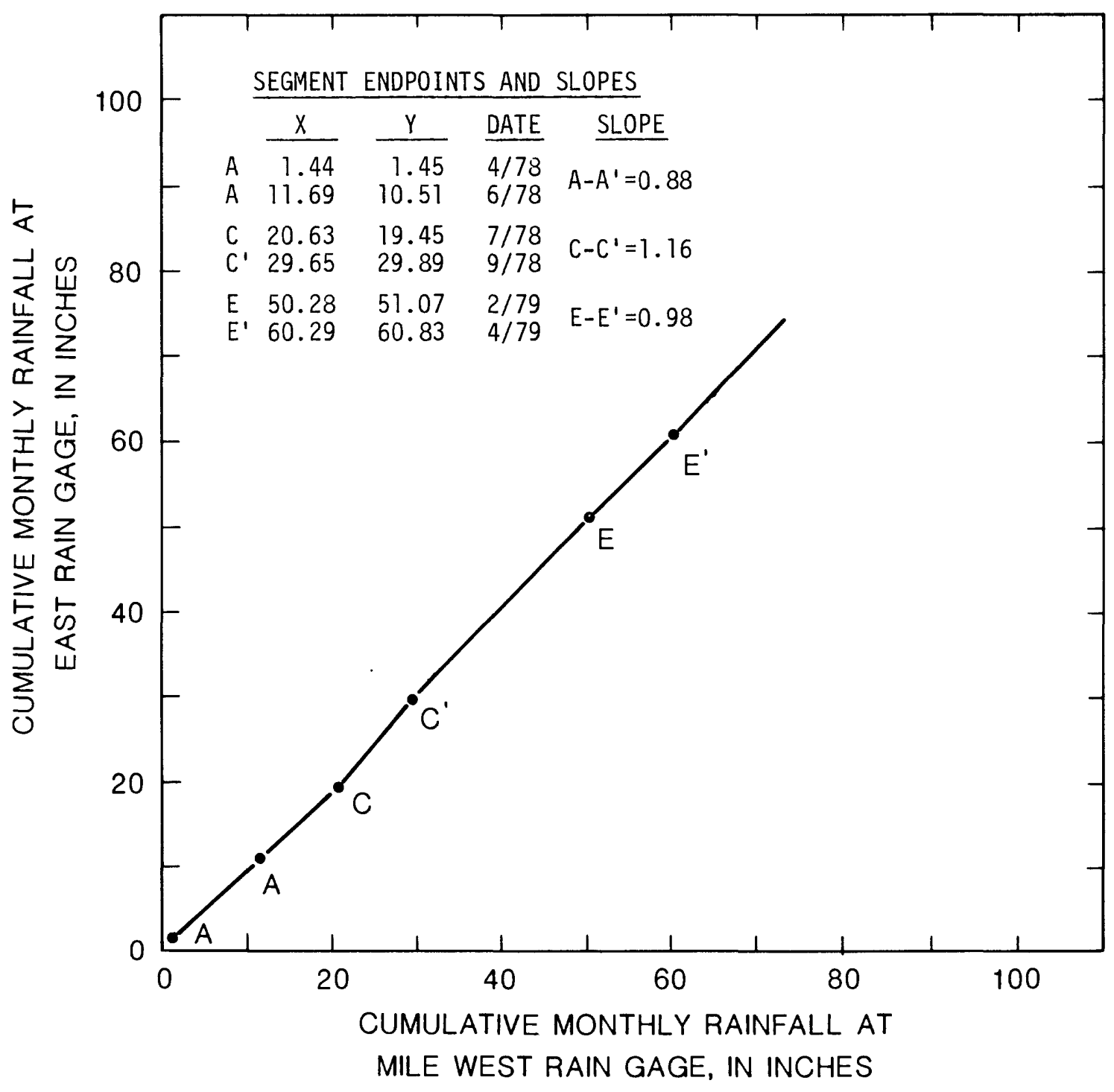

Figure 16.--Double-mass curve of rainfall data for East Rain gage and Mile West Rain gage for the period April 1978 to June 1979 . 


\section{CONCLUSIONS}

The drawdowns in wells in the Floridan aquifer system during the longterm test were calculated, using U. C. Deep as the control well, to be 4.3 feet at 4A, 4.1 feet at 5A, 1.0-foot at Mile West Middepth, and 0.4 foot at I-4 Deep. The pumping during this time was $560 \mathrm{gal} / \mathrm{min}$. Because of the possibility of small drawdown at U. C. Deep, the drawdowns at other wells are the drawdowns in excess of the drawdown at U. C. Deep.

Very little drawdown occurred in the water table. Drawdown in the surficial aquifer was difficult to assess because it was small and because watertable records lacked the proportionality of the Floridan aquifer system records. However, after an initial drawdown of 0.2 foot at the 1,000-foot Shallow well, there was an apparent recovery, and long-term drawdown averaged less than 0.2 foot. Drawdown at Mile West Shallow was too small to measure.

The results of the 5-day aquifer test conducted in 1976 indicate that an apparent state of equilibrium was established in which the ratio of the drawdown in the surficial aquifer to drawdown in the Floridan aquifer system was approximately 0.05 at this test site. This ratio may yield merely an upper limit on long-term water table drawdown. The conditions during the 5-day aquifer test were not representative of long-term conditions because there was no rainfall during that test. This means that a larger proportion of the water captured came from the supply that was already in the surficial aquifer before pumping started, and a lesser proportion came from the reduced rates of evapotranspiration and discharge to streams. On the long-term basis, it is from these latter sources that additional water is captured. The actual long-term average drawdown is therefore less than the drawdown that occurs during dry periods. Drawdown probably intermittently returns to its upper limit during times of drought.

The results of the long-term test may be extrapolated to determine the drawdown that would occur given a larger pumping rate. Using the principle of superposition, the drawdowns created by pumping from the same production well in the Floridan aquifer system may be determined. For example, if the pumping rate from well $1 \mathrm{~A}$ doubled, then the drawdown at well 4A would double. Similarly, the upper limit of drawdown in the surficial aquifer would double, although the average drawdown could be significantly less than the new limit. Results of the aquifer test should be applicable for estimating drawdowns caused by pumping in other areas of north-central Volusia County. However, because of the variability of characteristics of the Floridan aquifer system, the confining layer, and the surficial aquifer, the drawdown may be different from that predicted by extending the results of this test. 


\section{SELECTED REFERENCES}

Bush, P. W., 1978, Hydrologic evaluation of part of central Volusia County, Florida: U.S. Geological Survey Water-Resources Investigations $78-89,50 \mathrm{p}$.

Franke, 0. L., 1968, Double-mass-curve analysis of the effects of sewering on ground-water levels on Long Island, New York: U.S. Geological Survey Professional Paper 600-B, p. B205-B209.

Knochenmus, D. D., 1968, Surface drainage characteristics in Volusia County, Florida: Florida Division of Geology Map Series 30.

Knochenmus, D. D., and Beard, M. E., 1971, Evaluation of the quantity and quality of the water resources of Volusia County, Florida: Florida Bureau of Geology Report of Investigations 57, $59 \mathrm{p}$.

Lohman, S. W., 1972, Ground-water hydraulics: U.S. Geological Survey Professional Papex 1988, $21 \mathrm{p}$.

Miller, J. A., 1984, Geohydrologic framework of the Floridan aquifer system in Florida and in parts of Georgia, South Carolina, and Alabama: U.S. Geological Survey Professional Paper 1403-B, $284 \mathrm{p}$.

Searcy, J.K., and Hardison, C. H., 1960, Double-mass curves: U.S. Geological Survey Water-Supply Paper 154l-B, p. 31-66.

Simonds, E. P., Jr., McPherson, B. F., and Bush, P. W., 1980, Shallow groundwater conditions and vegetation classification, central Volusia County, Florida: U.S. Geological Survey Water-Resources Investigations Open-File Report 80-752, 1 sheet.

Wyrick, G. G., 1960, The ground-water resources of Volusia County, Florida: Florida Geological Survey Report of Investigations 22, $65 \mathrm{p}$.

--- 1961, Record of wells in Volusia County, Florida: Florida Geological Survey Information Circular 24, $96 \mathrm{p}$. 